\title{
Dietary ratio of animal:plant protein is associated with 24-h urinary iodine excretion in healthy school children
}

\author{
Gabriela Montenegro-Bethancourt ${ }^{1}$, Simone A. Johner ${ }^{1}$, Peter Stehle ${ }^{2}$ and Thomas Remer $^{1 *}$ \\ ${ }^{1}$ Department of Nutritional Epidemiology, Institute of Nutrition and Food Sciences, University of Bonn, \\ DONALD Study at the Research Institute of Child Nutrition, Heinstück 11, 44225 Dortmund, Germany \\ ${ }^{2}$ Department of Nutritional Physiology, Institute of Nutrition and Food Sciences, University of Bonn, Germany
}

(Submitted 11 June 2014 - Final revision received 27 February 2015 - Accepted 10 April 2015 - First published online 10 June 2015)

\begin{abstract}
Adequate dietary iodine intake in children is essential for optimal physical and neurological development. Whether lower dietary animal food and salt intake may adversely affect iodine status is under discussion. We examined the association between dietary animal:plant protein ratio with 24-h urinary iodine excretion (24-h UI, $\mu \mathrm{g} / \mathrm{d}$ ), and whether this is modified by salt intake. A 24-h UI was measured in 1959 24-h urine samples from 516 6- to 12-year-old participants of the Dortmund Nutritional and Anthropometric Longitudinally Designed Study. Parallel $3 \mathrm{~d}$ weighed food records were used to estimate dietary intakes. Protein sources were classified as dairy, animal and plant. A repeated-measures regression model (PROC MIXED) was used to analyse the effect of animal:plant protein ratios on 24-h UI. Animal: plant protein ratios ranged from 0.5 (95\% CI 0.4, 0.6) to 1.6 (95\% CI 1.4, 1.9) (lowest and highest quartile). After adjustment for total energy intake, main dietary iodine sources (dairy and salt intake), and further covariates, the inter-individual variation in animal:plant protein ratio was significantly associated with variation in 24-h UI. One unit higher animal:plant protein ratio predicted $6 \mu \mathrm{g} / \mathrm{d}$ higher $24-\mathrm{h}$ UI $(P=0 \cdot 002)$ in boys and $5 \mu \mathrm{g} / \mathrm{d}(P=0.03)$ in girls. This relationship was partially mediated by a higher salt intake at higher animal:plant protein ratios. These results suggest that lower consumption of animal protein is associated with a small decline in iodine excretion, partially mediated by decreased salt intake. Because limited salt and increased intake of plant-based foods are part of a preferable healthy food pattern, effective nutrition political strategies will be required in the future to ensure appropriate iodine nutrition in adherent populations.
\end{abstract}

Key words: Iodine: Children: Dietary protein: Animal protein

The essential role of iodine in thyroid hormone production and in the regulation of metabolism, growth and development has been extensively documented ${ }^{(1-3)}$. In most industrialised countries, the main dietary sources of iodine are iodised salt (approximately 50\%) and animal food products; of which, dairy products are the largest contributors, accounting for up to $40 \%$ of total iodine intake as has been shown and discussed by different authors ${ }^{(4-8)}$. Despite the global WHO-Universal Salt Iodisation Programme ${ }^{(9)}$, and regional strategies for iodine deficiency prevention and control, which in Europe included initiatives of legislation in the use of iodised salt in industrial food production ${ }^{(10)}$, and more recently in bread ${ }^{(11,12)}$, to mention some; iodine deficiencies in the European region still persist ${ }^{(13-15)}$.

Evidence from studies on the effect of diets containing little to no animal food products on iodine status is limited, but overall, the literature on this topic suggests that lower intakes of animal food can contribute to inadequate iodine intakes $^{(16-18)}$. Although there is still controversy about the impact of reducing dietary protein intake in children and potential health outcomes ${ }^{(19)}$, existing dietary guidelines for healthy eating, for example, the 'New American Plate' from the World Cancer Research Fund/American Institute for Cancer Research, advise the limitation in the intake of animal protein and to increase the intake of plant-based foods to prevent chronic diseases ${ }^{(20,21)}$. In addition, reducing $\mathrm{Na}$ intake in children is also part of the global health initiatives in the prevention of chronic diseases ${ }^{(22-25)}$. The existing typical Western diets, in contrast, are characterised by high intakes of processed foods, animal food products and salt $^{(26)}$. As studies suggest an association between processed foods as well as meat and increased salt intake ${ }^{(27-29)}$, the question arises whether, diets with lower animal foods (e.g. meats) and thereby possibly also decreased iodised salt intake may contribute to depleted iodine status as reflected in lower iodine excretion. To our knowledge, to date, no studies have assessed

Abbreviations: 24-h UI, 24-h urinary iodine excretion; DONALD, Dortmund Nutritional and Anthropometric Longitudinally Designed Study; EAR, estimated average requirements.

*Corresponding author: T. Remer, fax +49 231 711581, email remer@uni-bonn.de 
the association of animal- and plant-based food sources with urinary iodine status in children consuming typical Western diets. To specifically examine the long-term effect of diets predominantly animal or plant based on iodine status, we studied the 24-h urinary iodine excretion (24-h UI) in a sample of German schoolchildren providing multiple collections of both 24-h urine samples (with available Na excretion measurements) and parallel $3 \mathrm{~d}$ weighed food records, during the years 1993-2010. In Germany, a particularly improved iodine status in the population has been observed since 1993 parallel to legislation amendment, facilitating the use of iodised salt $(\mathrm{NaCl})$ in all processed foods ${ }^{(10,30)}$. However, the iodisation of salt used in households or for food production is still on a voluntary basis. During the last years (starting in 2004), the use of iodised salt by the food industry began to decrease in Germany, and by now encompasses only $<30 \%$ of total added salt, probably contributing to a negative trend in iodine status ${ }^{(4,5)}$.

We used the 'animal:plant protein ratio' of the children's habitual diet as an approach to characterise predominantly animal- or plant-based diets. We hypothesised that those children with healthier food patterns (low animal:plant protein ratio) have lower iodine excretion than children with high animal:plant protein ratio; the individual change in dietary sources of protein (animal-related to plant-based) and 24-h UI was evaluated using repeatedly collected dietary records and 24-h urines. As a second aspect, we aimed to investigate whether the potential association between animal:plant protein ratio and urinary iodine excretion may be mediated by an increase in salt consumption (namely iodised salt) with high animal protein diets.

\section{Subjects and methods}

\section{Design of the study}

The Dortmund Nutritional and Anthropometric Longitudinally Designed (DONALD) Study is an ongoing, observational open cohort study conducted at the DONALD Study Centre of the University of Bonn (formerly Research Institute of Child Nutrition) in Dortmund, Germany. Details on the study protocol have been published elsewhere ${ }^{(31)}$. Briefly, since 1985, detailed data on growth, diet and metabolism have been collected from healthy subjects between infancy and adulthood. In general, healthy infants are newly recruited each year and are first examined at the age of 3-6 months with continuing period follow-up examinations until reaching adulthood. The regular, non-invasive assessments (until the age of 18 years), that take place at intervals of about 1 year, include $3 \mathrm{~d}$ weighed food records, anthropometric measurements, collections of 24-h urine samples and interviews on lifestyle and medical assessments. The study was approved by the Ethics Committee of the Rheinische Friedrich-Wilhelms-University of Bonn (Germany). All examinations are performed with parental written consent and children's assent.

\section{Study sample}

For the purpose of this analysis, we used data from children aged 6-12 years participating in the DONALD Study from
January 1993 to December 2010 ( $n \quad 675$ and $n 2781$ measurements). To be eligible for the present analysis, children had to be within the age range, and providing at least two complete 24-h urine samples, each with concurrent $3 \mathrm{~d}$ weighed food record and anthropometrical data during the observational period. The individual number of 24-h urine samples and corresponding dietary records ranged from two to a maximum of seven possible measurements during the 17-year time period (for a 6-12 years age range). We excluded those observations that met one or more of the following criteria: (1) incompletely collected urine sample, i.e. when body weight-related $24-\mathrm{h}$ creatinine excretion rate was below the cut-off value of $0 \cdot 1 \mathrm{~mm} / \mathrm{kg}$ body weight per $\mathrm{d}^{(32)}$; (2) implausible dietary records, i.e. when the total recorded energy intake was inadequate in relation to the $\mathrm{BMR}^{(33)}$; (3) estimated total protein intake $<0.66 \mathrm{~g} / \mathrm{kg}$ of body weight, corresponding to the minimum maintenance requirement of protein ${ }^{(34)}$; or (4) use or intake of medication or supplements containing iodine. Hence, the final study sample for the present analysis consisted of 516 children ( $n$ 159 excluded), 51.4\% male and 48.6\% female, providing 1959 collected $24 \mathrm{~h}$ urines and related dietary and anthropometrical records (mean 3.8 measurements per subject over the total study period).

\section{Urinary assessment}

Annual 24-h urine collections for children older than 3 years were routinely performed in the DONALD Study usually on the third day of the $3 \mathrm{~d}$ weighed food record under standardised conditions. All urine samples collected during the 24-h collection period were immediately stored frozen at $-20^{\circ} \mathrm{C}$ in Extran (Extran, MA03; Merck) cleaned, preservative-free one litre plastic containers before being transported to the DONALD Study Centre (formerly, Research Institute of Child Nutrition) where they were stored at $-22^{\circ} \mathrm{C}$ until analysis ${ }^{(35)}$. Iodine concentration was determined in the 24-h urine samples by a modified Sandell-Kolthoff method after acidic wet-ashing of the samples ${ }^{(36)}$. Twenty-four hour $\mathrm{Na}$ excretion was measured by flame atomic absorption spectrometry with a Perkin Elmer 1100 Spectrometer (Perkin Elmer).

\section{Nutritional assessment}

Food consumption in the DONALD Study was assessed using $3 \mathrm{~d}$ weighed food records ${ }^{(31)}$. Energy and nutrient intakes were calculated from the nutrient values of the food ingredients using recipes available in the in-house database LEBTAB, which incorporates information from standard nutrient tables, product labels or recipe simulation based on the labelled ingredients and nutrients ${ }^{(37)}$. For the present analysis, the data were derived for each participant from the mean of the three dietary recording days. Composite dishes were disaggregated into their corresponding components, e.g. 'pizza' into wheat, cheese and water, and assigned to a food group category (e.g. cereals, legumes, fruits, vegetables, milk, cheese, meat and fish). The calculated protein intake was divided into (1) dairy protein including protein content 
from milk and whey-based milk products (yoghurt, buttermilk, cream, condensed milk and quark) and all varieties of cheese; (2) animal protein including protein content from eggs; all type of meats and chicken; fish and seafood and (3) plant protein including protein content from wheat and all wheat products, cereals (breakfast cereals, oats, sprouts); rice, potatoes, fruits, vegetables, mushrooms, soya products (only solid fraction of soya milk), legumes, nuts and pulses. Total protein was estimated as the sum of protein from all sources (dairy + animal protein + plant protein). Based on this classification, dietary animal:plant protein ratio were calculated. A priori, we decided to exclude dairy protein from the ratios for the following reasons: dairy products are often important constituents of the vegetarian food pattern, not just in Germany but also in other industrialised countries such as the USA, as literature suggests ${ }^{(38,39)}$. Milk has a relatively high iodine content ${ }^{(40-43)}$, and recent studies in German children suggest milk to be an important iodine source in the children's diet ${ }^{(4,5)}$. Due to these reasons, the inclusion of dairy in the animal:plant protein ratio may have introduced a correlation bias, which led to an overestimation of the association between the animal:plant protein ratio and 24-h UI. Milk and milk products whatsoever were included as separate covariate in the PROC MIXED model (see statistical analyses).

Regular use of iodised salt was reported in dietary records or parental interviews by nearly $100 \%$ of the participating children. $\mathrm{Na}(\mathrm{mg})$ and salt intake $(\mathrm{g})$ were estimated from the urinary $\mathrm{Na}$ excretion values $(1 \mathrm{~g} \mathrm{NaCl}=400 \mathrm{mg} \mathrm{Na})$.

\section{Anthropometry and parental data}

Anthropometric measurements of the DONALD participants were performed at the time of dietary recording and urine collection by trained personnel following standard procedures. Body weight was measured using an electronic scale (Seca 753 E; Seca Weighing and Measuring System) to the nearest $0 \cdot 1 \mathrm{~kg}$. Height was measured in a standing position to the nearest $0 \cdot 1 \mathrm{~cm}$ using a digital telescopic stadiometer (Harpenden), the children were dressed in underwear only and barefoot. BMI was calculated as body weight $(\mathrm{kg})$ divided by height $\left(\mathrm{m}^{2}\right)$. Sex- and age-independent BMI standard deviation scores were calculated using German National Reference data ${ }^{(44)}$. Body Surface Area was estimated using the formula of Du Bois \& Du Bois ${ }^{(45)}$.

At their child's admission to the study, parents provided information on educational background and they were also weighed and measured by the same personnel and equipment as the participating children. The weight was taken with light clothes and without shoes. Maternal education and maternal overweight (BMI $\geq 25 \mathrm{~kg} / \mathrm{m}^{2}$ ) were tested additionally as parameters that can potentially influence the dietary preferences in children ${ }^{(46)}$.

\section{Statistical analyses}

All statistical analyses were carried out by using SAS ${ }^{\circledR}$ (version 9.1.3; SAS, Inc.). In all statistical tests, a $P$-value $<0.05$ was considered as significant. Descriptive data for anthropometric, dietary and urinary parameters are presented as medians and interquartile ranges stratified by (1) sex; and (2) quartiles of animal:plant protein ratio. Quartiles of animal:plant protein ratio (excluding dairy protein) were grouped as low (lowest quartile), medium (middle two quartiles) and high (highest quartile). All observations (i.e. the repeated measurements at different time points from the same individual) were included for the calculations of medians. Sex differences and differences between animal:plant protein ratio quartiles were tested by repeated measures regression models (PROC MIXED, also linear mixed regression model in SAS) to account for the lack of independence that exists between repeated observations on the same person (comparable to a crosssectional analysis).

PROC MIXED, including both fixed and random effects, was also used for testing the longitudinal association of animal: plant protein ratio with 24-h UI $(\mu \mathrm{g} / \mathrm{d})$. An advantage of the MIXED procedure is that it does not exclude children from the analysis if they have missing data for a particular time point, but it analyses all variables on the assumption that any missing data are missing at random. The random component of the PROC MIXED model accounts among other for the lack of independence that exists between repeated observations on the same person.

The basic longitudinally regression model included animal: plant protein ratio, age, time and time $\times$ time as fixed effects. The variable 'time' (continuous, 1993-2010) was included as time, and time $\times$ time in the model because of the suggested variation of the $24-\mathrm{h}$ UI through the time period ${ }^{(4,30)}$. Potentially confounding factors influencing 24-h UI were considered as covariates. Only variables that substantially modified the coefficient of animal:plant protein ratio by $>10 \%$ in the basic models, or significantly predicted the outcome variable (24-h UI), or improved the fit statistic (Akaike's information criterion) were included in the subsequent multivariate analyses. All final multivariable models (model 1) included animal:plant protein ratio, age (years), time (chronological time of study years 1993-2010 and time $\times$ time), energy intake $(\mathrm{MJ} / \mathrm{d}), 24-\mathrm{h}$ urine volume $(\mathrm{ml} / \mathrm{d})$ and milk and milk products $(\mathrm{g} / \mathrm{d})$ as independent fixed effects. Diets with high animal protein intake may also be characterised by higher salt intake ${ }^{(27)}$, which is one of the most important iodine sources. Because salt intake might mediate the association between animal:plant protein ratio and iodine excretion, 24-h urinary $\mathrm{Na}$ excretion (as marker for salt intake) was tested in final multivariable models (model 2). To allow for the distinction between within-person and between-person effects of animal:plant protein ratio on 24-h UI, the data were first centred on the respective person-specific means of the animal:plant protein ratio over time (i.e. individual's mean), and these means were used to predict the betweenperson effects on 24-h UI (i.e. the associations of between-person differences in protein consumption with differences in mean 24-h UI between the subjects). After that, time-specific deviations from the person-specific means were calculated (i.e. individual value - the individual's mean) and used to test whether within-person changes on 
protein intakes were associated with within-person changes in $24-\mathrm{h} \mathrm{UI}^{(47,48)}$.

To estimate the prevalence of children at risk of inadequate iodine intake, 24-h UI excretion levels $(\mu \mathrm{g} / \mathrm{d})$ were compared to the estimated average requirements (EAR, i.e. $55 \mu \mathrm{g} / \mathrm{d}$ for $4-8$ years old; $62 \mu \mathrm{g} / \mathrm{d}$ for $9-13$ years old $)^{(49)}$, after considering a mean non-urinary iodine loss of $15 \%{ }^{(4)}$.

\section{Results}

A general description of the study sample with respect to anthropometry, dietary intakes and 24-h urine parameters is shown in Table 1 . In total, median (25th-75th interquartile range) of urinary iodine excretion (24-h UI) among these children was $75(56-98) \mu \mathrm{g} / \mathrm{d}$. Both iodine excretion $(\mu \mathrm{g} / \mathrm{d})$ and iodine concentration $(\mu \mathrm{g} / \mathrm{l})$ were significantly higher in boys than in girls, but no significance remained when corrected by individual energy intake. Regarding dietary intakes, median estimated protein intake was 1.7 (25th-75th interquartile range $1.4-2.0) \mathrm{g} / \mathrm{kg}$ for all children. Animal protein, including dairy, contributed $65.7 \%$ to the total protein intake, ranging from $17 \cdot 3$ to $88 \cdot 8 \%$.

Cross-sectional comparison of anthropometrical, urinary and dietary variables by quartiles of animal:plant protein ratio is shown in Table 2. Both urinary iodine excretion $(\mu \mathrm{g} / \mathrm{d})$ and iodine concentration $(\mu \mathrm{g} / \mathrm{l})$ were lower in the low animal protein diet than in the protein-rich diet (high ratio) in boys and girls; however, they were not significant. Overall, iodine excretion values below the EAR were observed in $14.3 \%$ ( $n$ 280) of the measurements. The proportion of observations below the EAR was higher in the lower animal protein eaters (12.8\% in boys and $19.2 \%$ in girls) than in the higher animal protein consumers $(10.3 \%$ in boys and $14.5 \%$ in girls) but statistically was not significant. Children in the high ratio category consumed more protein than children in the lower ratio category (differing by approximately $6 \mathrm{~g} / \mathrm{d}$ ). In the expected direction, $\mathrm{Na}$ excretion was higher when more animal protein was consumed (high ratio) but differed significantly only in boys. Proportion of mothers with lower education level was significantly higher in the high animal: plant protein ratio in boys and girls $(P<0 \cdot 0001)$. Proportion of maternal overweight was higher in the high-ratio group, but was significant only in girls $(P=0 \cdot 0002)$ (data no shown).

Results of the longitudinal linear mixed effects regression analyses (PROC MIXED) with urinary iodine excretion (24-h UI, $\mu \mathrm{g} / \mathrm{d}$ ) as dependent variable are shown in Table 3. $\beta$-Values for the individual time invariant mean values of animal:plant protein ratios represent the difference of 24-h UI $(\mu \mathrm{g} / \mathrm{d})$ when the dietary animal:plant protein ratio differs by one unit between the individuals across time. $\beta$-Values for intra-individual change indicate the within-person changes in the 24-h UI $(\mu \mathrm{g} / \mathrm{d})$ for a unit of change in animal:plant

Table 1. Anthropometric, nutritional and urinary characteristics of 6- to -12-year-old participants of the Dortmund Nutritional and Anthropometric Longitudinally Designed Study (1959 measurements)

(Median values, 25th-75th percentiles)

\begin{tabular}{|c|c|c|c|c|c|}
\hline & \multicolumn{2}{|r|}{ Boys } & \multicolumn{2}{|r|}{ Girls } & \multirow[b]{2}{*}{$P^{\star}$} \\
\hline & Median & 25th-75th percentiles & Median & 25th-75th percentiles & \\
\hline Subjects $(n)$ & & 265 & & 251 & \\
\hline Measurements ( $n$ ) & & 985 & & 974 & \\
\hline Age (years) & $9 \cdot 0$ & $7.02-10 \cdot 83$ & $9 \cdot 0$ & $7 \cdot 05-10 \cdot 88$ & \\
\hline \multicolumn{6}{|l|}{ Anthropometry } \\
\hline BMI & $16 \cdot 4$ & $15 \cdot 2-17 \cdot 8$ & $16 \cdot 4$ & $15 \cdot 1-18 \cdot 0$ & 0.27 \\
\hline BMI-SDS & -0.18 & $-0.76-0.44$ & -0.20 & $-0.80-0.48$ & 0.033 \\
\hline \multicolumn{6}{|l|}{ Urinary parameters } \\
\hline Iodine concentration $(\mu \mathrm{g} / \mathrm{l})$ & 109 & $81-143$ & 94 & $67-129$ & $<0.0001$ \\
\hline 24-h lodine excretion $(\mu \mathrm{g} / \mathrm{d})$ & 80 & $61-103$ & 70 & $53-91$ & $<0.0001$ \\
\hline 24-h lodine excretion $(\mu \mathrm{g} / \mathrm{M} \mathrm{J} / \mathrm{d})$ & $10 \cdot 9$ & $8 \cdot 4-13 \cdot 8$ & $10 \cdot 6$ & $8 \cdot 2-13 \cdot 7$ & 0.22 \\
\hline Urine volume $(\mathrm{ml} / \mathrm{d})$ & 730 & $554-966$ & 735 & $547-981$ & 0.86 \\
\hline Urine volume (ml/d/MJ) & 98 & $76-128$ & 110 & $83-146$ & $<0.0001$ \\
\hline $\mathrm{Na}$ excretion (mg/d) & 2025 & $1522-2610$ & 1762 & $1360-2610$ & $<0.0001$ \\
\hline $\mathrm{Na}$ excretion (mg/d/MJ) & 280 & $210-350$ & 270 & $0.21-0.34$ & 0.94 \\
\hline \multicolumn{6}{|l|}{ Dietary parameters } \\
\hline Estimated salt intake $(\mathrm{NaCL}, \mathrm{g} / \mathrm{d}) \dagger$ & $5 \cdot 1$ & $3 \cdot 8-6 \cdot 5$ & 4.4 & $3 \cdot 4-5 \cdot 8$ & $<0.0001$ \\
\hline Total energy $(\mathrm{MJ} / \mathrm{d})$ & $7 \cdot 4$ & $6 \cdot 6-8.3$ & $6 \cdot 6$ & $5.8-7.5$ & $<0.0001$ \\
\hline Protein (\% of energy) & $12 \cdot 7$ & $11.4-13.9$ & 12.5 & $11 \cdot 2-13.8$ & 0.21 \\
\hline Carbohydrates (\% of energy) & 52 & $47 \cdot 9-55 \cdot 6$ & 51.9 & $48 \cdot 3-55 \cdot 9$ & 0.25 \\
\hline Fat (\% of energy) & $35 \cdot 1$ & $31.9-38.8$ & $35 \cdot 3$ & $32 \cdot 0-38.9$ & 0.38 \\
\hline Protein per body weight (g/kg) & 1.8 & $1.52-2 \cdot 11$ & 1.6 & $1.36-1.88$ & $<0.0001$ \\
\hline Animal protein $(\mathrm{g} / \mathrm{d}) \ddagger$ & $15 \cdot 8$ & $11 \cdot 3-21.4$ & $14 \cdot 4$ & $10 \cdot 3-19 \cdot 1$ & $<0.0001$ \\
\hline Dairy protein $(\mathrm{g} / \mathrm{d}) \S$ & $17 \cdot 2$ & $12 \cdot 6-22 \cdot 6$ & $14 \cdot 1$ & $10 \cdot 4-19 \cdot 2$ & $<0.0001$ \\
\hline Plant protein $(\mathrm{g} / \mathrm{d})$ & 17.6 & $14 \cdot 3-21 \cdot 0$ & $16 \cdot 0$ & $13 \cdot 0-19 \cdot 2$ & $<0.0001$ \\
\hline
\end{tabular}

BMI-SDS, sex- and age-independent BMI standard deviation scores.

* Sex differences were tested with a linear mixed-effects regression model (PROC MIXED). PROC MIXED was used to account for the dependence of multiple measurements within the same child.

$\dagger$ Estimated from urinary $\mathrm{Na}(1 \mathrm{~g}$ of $\mathrm{NaCl}=0.4 \mathrm{~g} \mathrm{Na})$.

$\ddagger$ Animal protein includes protein from fish, poultry and all meat products.

$\S$ Dairy protein includes protein from milk and all milk products. 
Table 2. Comparison of anthropometric, nutritional and urinary characteristics between quartiles (Q1 and Q4) of animal:plant protein ratio of 6- to 12-year-old participants of the Dortmund Nutritional and Anthropometric Longitudinally Designed Study

(Median values, 25th-75th percentiles)

\begin{tabular}{|c|c|c|c|c|c|c|c|c|c|c|}
\hline & \multicolumn{5}{|c|}{ Boys } & \multicolumn{5}{|c|}{ Girls } \\
\hline & \multicolumn{2}{|c|}{ Low ratio (Q1) } & \multicolumn{2}{|c|}{ High ratio (Q4) } & \multirow[b]{2}{*}{$P_{\text {trend }}{ }^{*}$} & \multicolumn{2}{|c|}{ Low ratio (Q1) } & \multicolumn{2}{|c|}{ High ratio (Q4) } & \multirow[b]{2}{*}{$P_{\text {trend }}{ }^{*}$} \\
\hline & Median & $\begin{array}{l}25 \text { th-75th } \\
\text { percentiles }\end{array}$ & Median & $\begin{array}{l}25 \text { th-75th } \\
\text { percentiles }\end{array}$ & & Median & $\begin{array}{l}25 \text { th }-75 \text { th } \\
\text { percentiles }\end{array}$ & Median & $\begin{array}{l}25 \text { th }-75 \text { th } \\
\text { percentiles }\end{array}$ & \\
\hline Measurements $(n)$ & \multicolumn{2}{|c|}{243} & \multicolumn{2}{|c|}{244} & & \multicolumn{2}{|c|}{240} & \multicolumn{2}{|r|}{242} & \\
\hline $\begin{array}{l}\text { Ratio of animal:plant } \\
\text { protein } \dagger\end{array}$ & 0.49 & $0.35-0.55$ & $1 \cdot 61$ & $1.43-1.94$ & $<0.0001$ & 0.48 & $0.36-0.57$ & 1.54 & $1.39-1.86$ & $<0.0001$ \\
\hline Age & $9 \cdot 0$ & $7 \cdot 0-10 \cdot 6$ & $9 \cdot 0$ & $7 \cdot 0-10 \cdot 9$ & & $9 \cdot 0$ & $7 \cdot 0-10 \cdot 8$ & $9 \cdot 0$ & $7 \cdot 0-10 \cdot 8$ & \\
\hline \multicolumn{11}{|l|}{ Anthropometry } \\
\hline Body weight $(\mathrm{kg})$ & $30 \cdot 8$ & $25 \cdot 1-37 \cdot 2$ & 30.5 & $25 \cdot 7-38 \cdot 7$ & 0.85 & $29 \cdot 6$ & $24 \cdot 5-36 \cdot 4$ & $31 \cdot 0$ & $24 \cdot 7-38 \cdot 8$ & 0.32 \\
\hline $\mathrm{BSA}\left(\mathrm{m}^{2}\right)$ & 1.09 & $0.95-1.25$ & 1.08 & $0.96-1.28$ & 0.93 & 1.07 & $0.92-1.23$ & $1 \cdot 10$ & $0.94-1.26$ & 0.29 \\
\hline \multicolumn{11}{|l|}{ Urinary excretion parameters } \\
\hline lodine concentration $(\mu \mathrm{g} / \mathrm{l})$ & 107 & $81-139$ & 110 & $85-144$ & 0.23 & 89 & $68-127$ & 100 & $70-134$ & 0.54 \\
\hline lodine per $d(\mu \mathrm{g} / \mathrm{d})$ & 76 & $57-102$ & 84 & $64-108$ & 0.50 & 65 & $51-85$ & 73 & $54-97$ & $0 \cdot 13$ \\
\hline \% 24-h UI below EAR $\ddagger$ & $12 \cdot 8$ & & $10 \cdot 3$ & & 0.55 & $19 \cdot 2$ & & 14.5 & & 0.57 \\
\hline Na per $d(m g / d)$ & 1875 & $1420-2470$ & 2130 & $1600-2820$ & 0.027 & 1600 & $1200-2110$ & 1870 & $1490-2480$ & 0.053 \\
\hline Volume $(\mathrm{ml} / \mathrm{d})$ & 730 & $550-960$ & 725 & $550-980$ & 0.52 & 720 & $560-980$ & 710 & $545-980$ & 0.52 \\
\hline \multicolumn{11}{|l|}{ Dietary parameters } \\
\hline Total energy $(\mathrm{MJ} / \mathrm{d})$ & 7.4 & $6.5-8.4$ & 7.4 & $6.4-8.3$ & 0.76 & $6 \cdot 6$ & $5.6-7.5$ & $6 \cdot 6$ & $5 \cdot 8-7.5$ & 0.61 \\
\hline Total protein $(\mathrm{g} / \mathrm{d})$ & $50 \cdot 2$ & $41 \cdot 8-59 \cdot 4$ & $56 \cdot 3$ & $48 \cdot 2-66 \cdot 0$ & $<0.0001$ & $42 \cdot 0$ & $35 \cdot 2-50 \cdot 2$ & $49 \cdot 6$ & $43 \cdot 1-58 \cdot 3$ & $<0.0001$ \\
\hline Animal protein $(\mathrm{g} / \mathrm{d}) \S$ & 9.0 & $6.5-11.5$ & $24 \cdot 6$ & $20 \cdot 0-29.7$ & $<0.0001$ & $8 \cdot 1$ & $5 \cdot 5-10 \cdot 4$ & 21.9 & $17 \cdot 4-26 \cdot 2$ & $<0.0001$ \\
\hline Dairy protein $(g / d) \|$ & $19 \cdot 2$ & $14 \cdot 3-25 \cdot 8$ & $15 \cdot 7$ & $10 \cdot 8-20 \cdot 8$ & 0.0002 & 14.8 & $10 \cdot 4-20 \cdot 2$ & $13 \cdot 3$ & $9 \cdot 7-17 \cdot 2$ & 0.0005 \\
\hline Plant protein $(\mathrm{g} / \mathrm{d})$ & 20.5 & $17 \cdot 4-24 \cdot 2$ & 14.5 & $12 \cdot 2-17 \cdot 3$ & $<0.0001$ & 17.9 & $15 \cdot 0-21 \cdot 3$ & $13 \cdot 3$ & $10 \cdot 8-16 \cdot 2$ & $<0.0001$ \\
\hline Dietary fibre $(\mathrm{g} / \mathrm{d})$ & $20 \cdot 1$ & $16 \cdot 7-24 \cdot 0$ & $15 \cdot 2$ & $13 \cdot 0-18 \cdot 1$ & $<0.0001$ & $18 \cdot 1$ & $15 \cdot 5-22 \cdot 0$ & $14 \cdot 1$ & $11.5-17.3$ & $<0.0001$ \\
\hline
\end{tabular}

BSA, Body Surface Area; 24-h UI, 24-h urinary iodine excretion; EAR, estimated average requirements.

${ }^{*} P_{\text {trend }}$ was tested with PROC MIXED using the data of the total sample of 516 subjects with 1959 measurements. PROC MIXED was used to account for the dependence of multiple measurements within the same child. † Ratios estimated as animal:plant protein (excluding dairy).

$\ddagger$ Defined by using the $\operatorname{EAR}^{(49)}$ corrected for $15 \%$ non-urinary losses. Differences were tested with $\chi^{2}$ test.

$\S$ Animal protein, include fish, poultry and all meat products.

Dairy protein, include milk and all milk products. 
Table 3. Results of the linear mixed effects regression models (PROC MIXED) for the association between ratios of animal:plant protein intake and 24-h urinary iodine excretion (24-h UI, $\mu \mathrm{g} / \mathrm{d}$ ) in 516 6- to 12-year-old schoolchildren participants of the Dortmund Nutritional and Anthropometric Longitudinally Designed Study. Longitudinal analysis of 1959 measurements collected repeatedly between 1993 and 2010 stratified by sex

( $\beta$-Values and $95 \%$ confidence intervals)

\begin{tabular}{|c|c|c|c|c|c|c|c|c|c|c|c|c|}
\hline & \multicolumn{12}{|c|}{ Urinary iodine excretion $(\mu \mathrm{g} / \mathrm{d})$} \\
\hline & \multicolumn{6}{|c|}{$\begin{array}{c}\text { Boys } \\
\text { (n 985) measurements } \\
(n 265) \text { children }\end{array}$} & \multicolumn{6}{|c|}{$\begin{array}{c}\text { Girls } \\
\text { (n 974) measurements } \\
\text { (n 251) children }\end{array}$} \\
\hline & \multicolumn{3}{|c|}{ Between-person level $^{\star}$} & \multicolumn{3}{|c|}{ Within-person level† } & \multicolumn{3}{|c|}{ Between-person level $^{*}$} & \multicolumn{3}{|c|}{ Within-person level $†$} \\
\hline & $\beta$ & $95 \% \mathrm{Cl}$ & $P$ & $\beta$ & $95 \% \mathrm{Cl}$ & $P$ & $\beta$ & $95 \% \mathrm{Cl}$ & $P$ & $\beta$ & $95 \% \mathrm{Cl}$ & $P$ \\
\hline \multicolumn{13}{|c|}{ Animal:plant protein ratio } \\
\hline Model $1 \ddagger$ & $8 \cdot 7$ & 4,13 & 0.0002 & $6 \cdot 7$ & 3,11 & 0.004 & $7 \cdot 4$ & 3,12 & 0.001 & $2 \cdot 4$ & $-1,6$ & 0.18 \\
\hline Model $2 \S$ & $6 \cdot 3$ & 2,10 & 0.002 & $6 \cdot 6$ & 1,8 & 0.0003 & 4.5 & 1,9 & 0.028 & 1.8 & $-2,5$ & 0.29 \\
\hline
\end{tabular}

protein ratio across time. A higher animal:plant protein ratio was significantly associated with higher iodine excretion, before (model 1), and after adjustment for $\mathrm{Na}$ excretion (model 2); however, $\beta$-values diminished after adjustment for $\mathrm{Na}$ excretion. Overall, the effect strength was greater between individuals than within individuals (different $\beta$-values and significance). Fig. 1 graphically illustrates the proportions of protein sources by animal:plant protein ratio category (low, middle and high) and its effect on 24-h UI, obtained from adjusted means of the 24-h UI from the PROC MIXED model.

In addition, a separate analysis was conducted using the same PROC MIXED model to evaluate the strength of association of the animal:plant protein ratio and 24-h UI, including dairy protein in the animal:plant protein ratios (dairy + animal-/plant-based protein). The results of this analysis were similar to those presented in Table 3; the effect estimates were only slightly enhanced. For instance, in boys at the between-person level, the effect estimate increased from $8.7 \mu \mathrm{g} / \mathrm{d}$ (ratios excluding dairy) to $8.9 \mu \mathrm{g} / \mathrm{d}$ (including dairy) (model 1) and $6 \cdot 3$ to $9 \cdot 1 \mu \mathrm{g} / \mathrm{d}$ (model 2). In girls, the corresponding values were $7 \cdot 4 \mu \mathrm{g} / \mathrm{d}$ and $7 \cdot 4 \mu \mathrm{g} / \mathrm{d}$ (same values) (model 1) and 4.5 to $7 \cdot 4 \mu \mathrm{g} / \mathrm{d}$ (model 2) respectively.

\section{Discussion}

In the present longitudinal analysis of children consuming a diet characterised by relatively high protein intake (typical Western diet), we examined the importance of changes in the proportion of animal to plant protein for changes in iodine status, and the corresponding role of salt intake. Our findings suggest that a high ratio of animal:plant protein is associated with greater iodine excretion $(\mu \mathrm{g} / \mathrm{d})$, even if other relevant dietary sources of iodine (e.g. salt intake) are controlled for.

Suggestive evidence of a higher risk of sub-optimal iodine status has already been proposed when diets lack animal food products. This notion builds on studies mainly conducted in adults, who are vegetarians or vegans, which may lead to deficits in iodine as well in other micronutrients $^{(16,17,50)}$, whereas in children this information is scarce. Most previous cross-sectional studies in children characterising iodine status reported urinary iodine concentration $(\mu \mathrm{g} / \mathrm{l})$, but usually lacked data on the dietary habitual intake ${ }^{(6,7,12,51,52)}$. In our longitudinal analysis, we were able to simulate different dietary protein patterns, and quantify the effect of lower animal food intake, resembling almost a vegetarian diet, on iodine excretion. One example to illustrate the apparent effect of increasing the animal:plant protein ratio on the 24-h UI can be deduced from our model. Assuming a $50 \mathrm{~g}$ total protein intake (approximately average protein intake for boys in the low-animal:plant protein ratio), made up by $20 \mathrm{~g}$ from dairy, $10 \mathrm{~g}$ from animal and $20 \mathrm{~g}$ from plant protein, the estimated animal:plant protein ratio is 0.5 . Increasing the animal:plant protein ratio by one unit would modify the proportion of the sources, i.e. an intake of $18 \mathrm{~g}$ from animal protein, and $12 \mathrm{~g}$ of plant-protein, keeping the dairy protein in $20 \mathrm{~g}$. Theoretically, according to our adjusted model (model 2), about $6 \mu \mathrm{g} / \mathrm{d}$ higher 24-h UI would be expected between boys with otherwise similar dietary intakes (including $\mathrm{Na}$ intake) and within the same boy, with one unit increase in animal:plant protein ratio. In girls, no association was found between an increase in the ratio and changes at the within person level, possibly due to smaller individual changes that we were not able to fully identify.

One possible mechanism thought to explain the positive association of animal:plant protein ratios with iodine excretion is the suggested association between $\mathrm{Na}$ intake and consumption of animal foods. The main dietary sources of $\mathrm{Na}$ ingested by children in Europe and Northern America are processed foods, often of animal origin ${ }^{(28,53,54)}$. Longitudinal analysis suggests that meat intake (especially cold cuts) increases 24-h $\mathrm{Na}$ excretion as earlier reported in a group of DONALD children $^{(27)}$. These findings were confirmed by our analysis as we observed higher $\mathrm{Na}$ intake in the high animal:plant protein ratio category (Table 2). However, the positive association of animal:plant protein ratio with $24-\mathrm{h}$ UI in the 

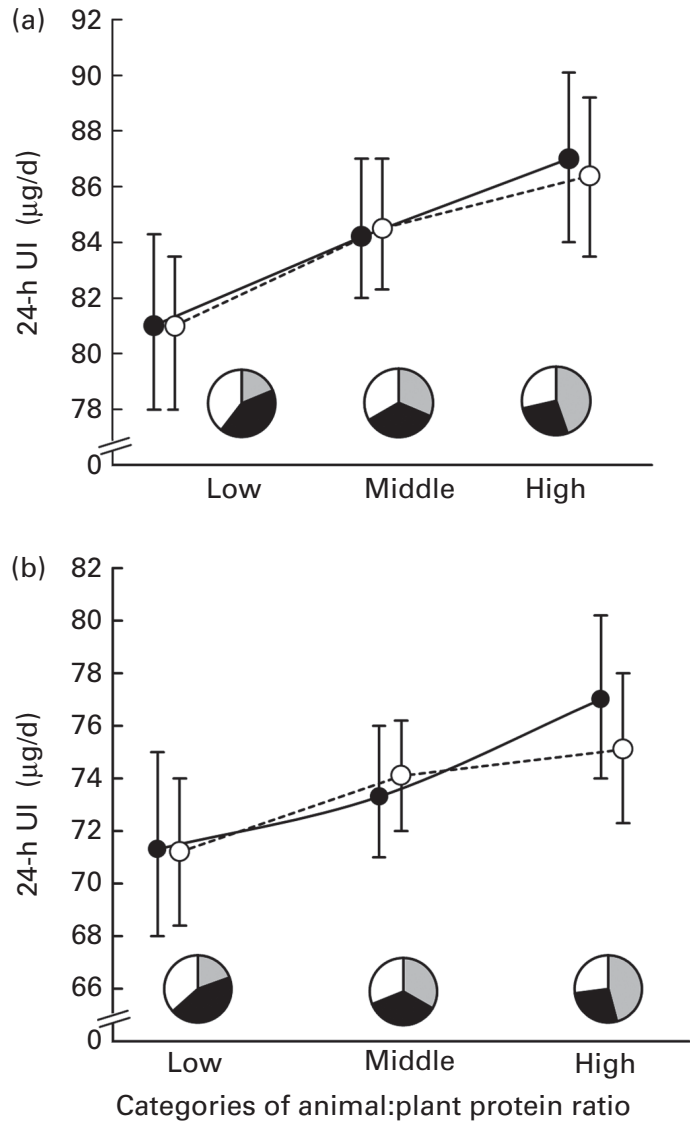

Fig. 1. Least-squares means (95\% confidence intervals) of 24 -h urinary iodine excretion (24-h $\mathrm{UI}, \mu \mathrm{g} / \mathrm{d}$ ) by category of animal:plant protein ratio in (a) boys and (b) girls. Model 2 (Table 3 ) of the multivariable-adjusted linear mixed models was used for prediction. $P$ for continuous trend refers to the $P$ values obtained in linear regression models with 24-h $\mathrm{UI}$ as continuous variable. Between-person changes $(P$ for trend $=0.0023$ in boys and $P$ for trend $=0.028$ in girls); $O$, within-person changes $(P$ for trend $=0.0003$ in boys and $P$ for trend $=0.29$ in girls). Medians of animal:plant protein ratio protein in low (Q1), middle (Q2-Q3) and high (Q4) categories were in boys: 0.48, 0.90 and 1.61; in girls: $0.47,0.92$ and 1.54 , respectively. The pie graph presents the different proportions of protein sources in the categories of animal:plant protein ratios: animal (grey), dairy (white) and plant-based (black). Animal protein contribution by ratios category was (a) in boys: low $19 \%$, middle $31 \%$ and high $45 \%$; (b) in girls: low $20 \%$, middle $33 \%$ and high $46 \%$, respectively.

longitudinal PROC MIXED model remained significant after adjustment for $\mathrm{Na}$ excretion, albeit with somewhat reduced effect estimates ( $\beta$-values of the animal:plant protein ratio). Therefore, the association between animal:plant protein ratio and 24-h UI in children seems to be only partially mediated by the amount of $\mathrm{Na}$ intake. It is interesting that when including dairy protein in the animal protein fraction from the animal:plant protein ratios predicted a quite similar increase of $24-\mathrm{h}$ UI, compared to the $\beta$-values when the dairy is excluded from the ratios. It is possible that the relatively high but constant contribution from the dairy group observed over the whole range of animal and plant protein categories (Fig. 1, pie graphs) explains the observed results.

Traditionally, the iodine status of populations is measured in terms of urinary iodine concentration $(\mu \mathrm{g} / \mathrm{l})$, generally obtained from spot urine samples ${ }^{(55,56)}$. More recently, it has been acknowledged that whenever feasible, 24-h UI $(\mu \mathrm{g} / \mathrm{d})$ should be the 'reference standard' for measuring iodine intake, as it incorporates urine volume, which can strongly affect dilution of the sample and therefore iodine concentration $^{(4,57,58)}$. With our analysis, which comprises a large number of 24-h urine samples (approximately 2000), we were able to confirm the importance of using 24-h UI ( $\mu \mathrm{g} /$ d) instead of concentration $(\mu \mathrm{g} / \mathrm{l})$ to define the iodine status. Based on the WHO $100 \mu \mathrm{g} / \mathrm{l}$ cut-off for iodine adequacy, our observed median concentration in boys $(109 \mu \mathrm{g} / \mathrm{l})$ suggests sufficiency, and in girls $(94 \mu \mathrm{g} / \mathrm{l})$ modest insufficiency. Due to an often better hydration status in females compared to males ${ }^{(59,60)}$, such a difference is not unexpected; accordingly, energy-corrected $24 \mathrm{~h}$ excretion rates of iodine (Table 1) denoted that no sex differences exist.

As trends towards alternative nutrition practices, i.e. preferences to consume organic foods, use of no iodised salt, and vegetarian diets, are becoming more popular in European children $^{(61,62)}$, the issue of what constitutes an optimum diet and micronutrient composition has important public health implications. In an effort to achieve healthier diets, even slight changes in food sources, especially in animal products (a decline in dairy, eventually, increasing grain intakes), may potentially negatively affect micronutrients such as iodine as recently observed by Perrine et $a l .{ }^{(6)}$ in a group of USA schoolchildren. Accordingly, when the subjects of the present analysis were divided into low $v$. high animal:plant protein ratios, the proportion of children with iodine status below EAR was higher in the lower animal foods consumers, although the differences were not significant. Also, the observed effect estimates for a change of animal:plant protein ratio for 24-h UI were small. A change in the animal:plant protein ratio of about one unit predicted a difference in 24-h UI of approximately $6 \mu \mathrm{g} / \mathrm{d}$, equalling to about $10 \%$ of the EAR. Nonetheless, this dietary factor should not be overlooked as a long-term etiological risk factor that might contribute to cause iodine deficiency disorders in children, such as cognitive performance as literature suggests ${ }^{(63,64)}$. In particular, with regard to the planned salt reduction measures that will also reduce the intake of iodised salt (the main iodine source for children), the achievement of an adequate intake in nearly all children is an important goal.

Discrepancies on the adequate amounts and sources of protein intake in children exist. It has been shown in epidemiological and clinical studies that the amounts of dietary protein intake as well as its sources are important in the prevention or risk increase of chronic diseases, as reviewed in the report by Hörnell et $a l^{(19)}$. In the present study population, the median protein intake $(1.7 \mathrm{~g} / \mathrm{kg})$ was higher than the $0.9 \mathrm{~g} / \mathrm{kg}$ recommended for German children ${ }^{(65)}$; however, the overall contribution was within the range of representative German schoolchildren's dietary protein intake $\left(10-15 \%\right.$ of energy) ${ }^{(66)}$.

Strengths of the present study included the longitudinal design, with two to seven repeated measurements throughout childhood for each individual and the available data in a relatively large number of children, which better allowed us to use models more suitable for the evaluation of the association of 
diet with urinary biomarkers (24-h UI) than models based on cross-sectional designs. Even though single 24-h UI collections do not reflect habitual iodine intake ${ }^{(58)}$, the repeated measures of dietary intakes concomitant with analysis of urine samples in the same subject allows both assessment of the gross average iodine status over years and the influence thereupon of the children's changes in dietary components (from year to year).

As it is recognised, the participants of the DONALD Study are characterised by a higher socioeconomic status than the overall German population $^{(31)}$, and do not represent subjects with rather extreme dietary characteristics, e.g. a very high intake of $\mathrm{Na}$, as present in other population groups ${ }^{(66)}$. However, despite the homogeneity of our sample, we could still observe significant associations regarding the maternal education with the children's preferred protein sources. The higher proportion of mothers with a higher level of education in the low animal:plant protein ratio category suggest that homes with better educated mothers probably are more likely to adopt more healthy food patterns, which potentially may in turn lead to a moderate deficiency in iodine supply.

In conclusion, the present study shows a positive association between higher ratio of animal:plant protein and iodine status in children. Accordingly, children with healthier and therefore more desirable food patterns (lower intake of animal protein) demonstrate somewhat lower iodine excretion. As many children in Western populations are probably already in the highest animal:plant protein ratio, increasing animal protein intake would not be advisable. To nonetheless ensure adequate iodine nutrition, alternative prophylactic measures to prevent iodine deficiency are needed. One solution could be the mandatory use of iodised salt in processed foods and for bread ${ }^{(12,67,68)}$ (on a voluntary basis, which currently in Germany is only $<30 \%{ }^{(5)}$ ) in addition to the use of iodised salt at home. Furthermore, substituting some of the meat protein for animal foods with higher iodine content (e.g. fish) may also benefit the iodine nutrition in those consuming Western type diets. Altogether, the existing dietary recommendations that advise the limitation in the intake of animal protein and to increase the plantbased foods to prevent chronic diseases do not contradict with adequate iodine nutrition; however, potentially, they may do so if no further actions towards general iodine prophylaxis measures are taken.

\section{Acknowledgements}

The participation of all children and their families in the DONALD Study is gratefully acknowledged. We also thank the staff of the Research Institute of Child Nutrition for carrying out the anthropometric measurements, dietary data and for urine laboratory analyses.

The DONALD Study was supported by the Ministry of Innovation, Science, Research and Technology of North RhineWestphalia, Germany. G. M.-B. received a research fellowship from the Deutscher Akademischer Austausch Dienst.

The authors' contributions are as follows: T. R. and G. M.-B. designed the research; T. R. was responsible for the urine analysis; G. M.-B. with S. A. J. performed statistical analysis;
P. S. critically revised the manuscript for important intellectual content. All authors were involved in data interpretation and reviewing the manuscript. G. M.-B. wrote the manuscript and T. R. had primary responsibility for final content. All authors made contributions to and approved the final manuscript.

The authors declare no personal or financial conflicts of interest.

\section{References}

1. Zimmermann MB (2009) Iodine deficiency. Endocr Rev 30 376-408.

2. Bougma K, Aboud FE, Harding KB, et al. (2013) Iodine and mental development of children 5 years old and under: a systematic review and meta-analysis. Nutrients $\mathbf{5}$, 1384-1416.

3. Gunnarsdottir I \& Dahl L (2012) Iodine intake in human nutrition: a systematic literature review. Food Nutr Res $\mathbf{5 6}$ (epublication 9 October 2012).

4. Johner SA, Gunther AL \& Remer T (2011) Current trends of 24-h urinary iodine excretion in German schoolchildren and the importance of iodised salt in processed foods. $\mathrm{Br} \mathrm{J}$ Nutr 106, 1749-1756.

5. Johner SA, Thamm M, Nöthlings U, et al. (2013) Iodine status in preschool children and evaluation of major dietary iodine sources: a German experience. Eur J Nutr 52, 1711-1719.

6. Perrine CG, Sullivan KM, Flores R, et al. (2013) Intakes of dairy products and dietary supplements are positively associated with iodine status among U.S. children. $J$ Nutr 143 $1155-1160$.

7. Watutantrige Fernando S, Barollo S, Nacamulli D, et al. (2013) Iodine status in schoolchildren living in northeast Italy: the importance of iodized-salt use and milk consumption. Eur J Clin Nutr 67, 366-370.

8. Haldimann M, Alt A, Blanc A, et al. (2005) Iodine content of food groups. J Food Compost Anal 18, 461-471.

9. WHO/UNICEF/ICCIDD (2007) Assessment of Iodine Deficiency Disorders and Monitoring their Elimination: a Guide for Program Managers. Geneva: World Health Organization.

10. Remer $\mathrm{T} \&$ N Neubert A (1998) A never-ending story of an insufficient iodine status without mandatory iodization of foods? - a German experience. J Clin Endocrinol Metab 83, 3755-3756.

11. Rasmussen LB, Ovesen L, Christensen T, et al. (2007) Iodine content in bread and salt in Denmark after iodization and the influence on iodine intake. Int J Food Sci Nutr 58, 231-239.

12. Vandevijvere S, Mourri AB, Amsalkhir S, et al. (2012) Fortification of bread with iodized salt corrected iodine deficiency in school-aged children, but not in their mothers: a national cross-sectional survey in Belgium. Thyroid 22, 1046-1053.

13. Zimmermann MB \& Andersson M (2012) Update on iodine status worldwide. Curr Opin Endocrinol Diabetes Obes 19, 382-387.

14. Zimmermann MB (2013) Iodine deficiency and excess in children: worldwide status in 2013. Endocr Pract 19, 839-846.

15. Zimmermann MB (2010) Symposium on 'Geographical and geological influences on nutrition': iodine deficiency in industrialised countries. Proc Nutr Soc 69, 133-143.

16. Krajcovicová-Kudlácková $\mathrm{M}$, Bucková $\mathrm{K}$, Klimes $\mathrm{I}$, et al. (2003) Iodine deficiency in vegetarians and vegans. Ann Nutr Metab 47, 183-185.

17. Remer T, Neubert A \& Manz F (1999) Increased risk of iodine deficiency with vegetarian nutrition. Br J Nutr 81, 45-49. 
18. Lightowler HJ \& Davies GJ (1998) Iodine intake and iodine deficiency in vegans as assessed by the duplicate-portion technique and urinary iodine excretion. $\mathrm{Br} J$ Nutr $\mathbf{8 0}$, $529-535$

19. Hörnell A, Lagström H, Lande B, et al. (2013) Protein intake from 0 to 18 years of age and its relation to health: a systematic literature review for the 5th Nordic Nutrition Recommendations. Food Nutr Res 57 (epublication 23 May 2013)

20. World Cancer Research Fund/American Institute for Cancer Research (2007) Food, Nutrition, Physical Activity, and the Prevention of Cancer: a Global Perspective. Washington DC: AICR.

21. American Institute for Cancer Research (2013) The New American Plate. http://www.aicr.org/new-american-plate/ (accessed 18 February 2015)

22. Campbell NR, Dary O, Cappuccio FP, et al. (2012) Need for coordinated programs to improve global health by optimizing salt and iodine intake. Rev Panam Salud Publica 32, 281-286.

23. Institute of Medicine (2005) Dietary Reference Intakes for Water, Potassium, Sodium, Chloride, and Sulfate, 1st edn. Washington, DC: The National Academies Press.

24. World Health Organization (2012) Guideline: sodium intake for adults and children. http://www.who.int/nutrition/ publications/guidelines/sodium_intake_printversion.pdf (accessed 5 April 2013).

25. U.S. Department of Agriculture \& U.S. Department of Health and Human Services (2010) Dietary Guidelines for Americans, 7th edn. Washington D.C: US Government Printing Office.

26. Cordain L, Eaton SB, Sebastian A, et al. (2005) Origins and evolution of the Western diet: health implications for the 21st century. Am J Clin Nutr 81, 341-354.

27. Alexy U, Cheng G, Libuda L, et al. (2012) 24 h-Sodium excretion and hydration status in children and adolescents - results of the DONALD Study. Clin Nutr 31, 78-84.

28. Libuda L, Kersting M \& Alexy U (2012) Consumption of dietary salt measured by urinary sodium excretion and its association with body weight status in healthy children and adolescents. Public Health Nutr 15, 433-441.

29. Thomson BM (2009) Nutritional modelling: distributions of salt intake from processed foods in New Zealand. $\mathrm{Br} J$ Nutr 102, 757-765.

30. Remer T, Fonteyn N, Alexy U, et al. (2006) Longitudinal examination of 24-h urinary iodine excretion in schoolchildren as a sensitive, hydration status-independent research tool for studying iodine status. Am J Clin Nutr 83, 639-646.

31. Buyken AE, Alexy U, Kersting M, et al. (2012) The DONALD cohort. An updated overview on 25 years of research based on the Dortmund Nutritional and Anthropometric Longitudinally Designed study. Bundesgesundheitsblatt Gesundheitsforschung Gesundheitsschutz 55, 875-884

32. Remer T, Neubert A \& Maser-Gluth C (2002) Anthropometrybased reference values for 24-h urinary creatinine excretion during growth and their use in endocrine and nutritional research. Am J Clin Nutr 75, 561-569.

33. Schofield WN (1985) Predicting basal metabolic rate, new standards and review of previous work. Hum Nutr Clin Nutr 39, Suppl. 1, 5-41.

34. Garlick PJ (2006) Protein requirements of infants and children. Nestle Nutr Workshop Ser Pediatr Program 58, 39-47.

35. Remer T, Montenegro-Bethancourt G \& Shi L (2014) Longterm urine biobanking: storage stability of clinical chemical parameters under moderate freezing conditions without use of preservatives. Clin Biochem 47, 307-311.

36. Lorenz-Wawschinek O, Tiran B, Eber O, et al. (1994) Photometric determination of iodine in urine. Exp Clin Endocrinol 102, 357-358
37. Sichert-Hellert W, Kersting M, Chahda C, et al. (2007) German food composition database for dietary evaluations in children and adolescents. J Food Comp Anal 20, 63-70.

38. Haddad EH \& Tanzman JS (2003) What do vegetarians in the United States eat? Am J Clin Nutr 78, Suppl. 3, 626S-632S.

39. Deutsche Gesellschaft für Ernährung e.V (2008) Ernährungsbericht (The Nutrition Report): 2008. Bonn: Deutsche Gesellschaft für Ernährung (German Nutrition Society).

40. Bath SC, Button S \& Rayman MP (2012) Iodine concentration of organic and conventional milk: implications for iodine intake. Br J Nutr 107, 935-940.

41. Johner SA, Nida K, von Jahreis G, et al. (2012) Time trends and seasonal variation of iodine content in German cow's milk - investigations from Northrhine-Westfalia (article in German). Berl Munch Tierarztl Wochenschr 125, 76-82.

42. Soriguer F, Gutierrez-Repiso C, Gonzalez-Romero S, et al. (2011) Iodine concentration in cow's milk and its relation with urinary iodine concentrations in the population. Clin Nutr (Edinburgh, Scotland) 30, 44-48.

43. Köhler M, Fechner A, Leiterer M, et al. (2011) Iodine content in milk from German cows and in human milk: new monitoring study. Trace Elem Electrol 29, 119-126.

44. Neuhauser N, Schienkiewitz A, Schaffrath Rosario A, et al. (2011) Referenzperzentile für anthropometrische Maßzablen und Blutdruck aus der Studie zur Gesundheit von Kindern und Jugendlichen in Deutschland (KiGGS) 2003-2006 (Reference Percentiles for Anthropometric Measures and Blood Pressure from the Study on Health in Children and Adolescents in Germany (KiGGS) 2003-2006). Berlin: Robert Koch Institut

45. Du Bois D \& Du Bois EF (1989) A formula to estimate the approximate surface area if height and weight be known 1916. Nutrition 5, 303-311; discussion 312-313.

46. Lin Y, Bolca S, Vandevijvere S, et al. (2011) Dietary sources of animal and plant protein intake among Flemish preschool children and the association with socio-economic and lifestyle-related factors. Nutr J 10, Epublication 25 September 2011.

47. Curran PJ \& Bauer DJ (2011) The disaggregation of withinperson and between-person effects in longitudinal models of change. Annu Rev Psychol 62, 583-619.

48. Hoffman L \& Stawski RS (2009) Persons as contexts: evaluating between-person and within-person effects in longitudinal analysis. Res Hum Dev 6, 97-120.

49. Food and Nutrition Board \& Institute of Medicine (2001) Dietary Reference Intakes for Vitamin A, Vitamin K, Arsenic, Boron, Chromium, Copper, Iodine, Iron, Manganese, Molybdenum, Nickel, Silicon, Vanadium, and Zinc. Washington, DC: The National Academy Press.

50. Leung AM, Lamar A, He X, et al. (2011) Iodine status and thyroid function of Boston-area vegetarians and vegans. J Clin Endocrinol Metab 96, E1303-E1307.

51. Verkaik-Kloosterman J, van't Veer P \& Ocké MC (2010) Reduction of salt: will iodine intake remain adequate in The Netherlands? Br J Nutr 104, 1712-1718.

52. Skeaff SA, Thomson CD, Wilson N, et al. (2012) A comprehensive assessment of urinary iodine concentration and thyroid hormones in New Zealand schoolchildren: a cross-sectional study. Nutr J 8, 11-31.

53. National Cancer Institute (2005) Sources of Sodium among the US Population, 2005-06. Applied Research Program Web site. National Cancer Institute. Updated 11 April 2014. http://appliedresearch.cancer.gov/diet/foodsources/ sodium/ (accessed May 2015). 
54. Huybrechts I, De Keyzer W, Lin Y, et al. (2012) Food sources and correlates of sodium and potassium intakes in Flemish pre-school children. Public Health Nutr 15, 1039-1046.

55. Andersson M, Karumbunathan V \& Zimmermann MB (2012) Global iodine status in 2011 and trends over the past decade. J Nutr 142, 744-750.

56. Zimmermann MB \& Andersson M (2012) Assessment of iodine nutrition in populations: past, present, and future. Nutr Rev 70, 553-570.

57. Dary O (2011) Time to refine the use of urinary iodine to assess iodine intakes in populations. BrJ Nutr 106, 1630-1631.

58. Vejbjerg P, Knudsen N, Perrild H, et al. (2009) Estimation of iodine intake from various urinary iodine measurements in population studies. Thyroid 19, 1281-1286.

59. Ebner A \& Manz F (2002) Sex difference of urinary osmolality in German children. Am J Nephrol 22, 352-355.

60. Montenegro-Bethancourt G, Johner SA \& Remer T (2013) Contribution of fruit and vegetable intake to hydration status in schoolchildren. Am J Clin Nutr 98, 1103-1112.

61. Gorczyca D, Prescha A, Szeremeta K, et al. (2013) Iron status and dietary iron intake of vegetarian children from Poland. Ann Nutr Metab 62, 291-297.

62. van Winckel M, Vande Velde S, De Bruyne R, et al. (2011) Clinical practice: vegetarian infant and child nutrition. Eur J Pediatr 170, 1489-1494.
63. Gordon RC, Rose MC, Skeaff SA, et al. (2009) Iodine supplementation improves cognition in mildly iodine-deficient children. Am J Clin Nutr 90, 1264-1271.

64. Santiago-Fernandez P, Torres-Barahona R, Muela-Martínez JA, et al. (2004) Intelligence quotient and iodine intake: a cross-sectional study in children. J Clin Endocrinol Metab 89, 3851-3857.

65. German Nutrition Society DACH (2008) Reference Values for Nutrient Intake, 1st ed. Frankfurt a. M., Germany: Umschau Verlag.

66. Mensing G, Heseker H \& Richter A (2007) Forschungsbericht Ernährungsstudie als KiGGSModul (EsKiMo). (Eating Study as a KiGGS Module (EsKiMo)). http://www.bmelv.de/ SharedDocs/Downloads/Ernaehrung/EsKiMoStudie.pdf? blob= publicationFile (accessed November 2013).

67. Harris MJ, Jooste PL \& Charlton KE (2003) The use of iodised salt in the manufacturing of processed foods in South Africa: bread and bread premixes, margarine, and flavourants of salty snacks. Int J Food Sci Nutr 54, $13-19$.

68. Clifton VL, Hodyl NA, Fogarty PA, et al. (2013) The impact of iodine supplementation and bread fortification on urinary iodine concentrations in a mildly iodine deficient population of pregnant women in South Australia. Nutr J (epublication 15 March 2013). 